ÇOMÜ Uluslararası Sosyal Bilimler Dergisi 3 (2), 407-428, 2018

COMU International Journal of Social Sciences 3 (2), 407-428, 2018

\title{
Diyarbakır Arkeoloji ve Etnoğrafya Müzesi Deposunda Bulunan Bir Grup Mezar Taşı
}

Sahure YARİŞ *

Öz

Maddi kültür varlıklarımız içerisinde önemli bir yere sahip olan mezar taşları; tarih, sanat, edebiyat ve kültürel açıdan değerlidir. Türk-İslam sanatı açısından önemli bir grubu oluşturan bu eserler, hem geç anlaşılmış hem de gerektiği gibi korunamamıştır. Bu nedenle bir kısmı yok olup gitmiştir. Bir kısmı ise müze depolarında bulunmaktadır. Bu çalışmada Diyarbakır Arkeoloji ve Etnoğrafya Müzesi deposunda bulunan on ikisi baştaşı, altı taştan biri ayaktaşı, ikisi çatma lahite ait yan taşı, üçü ise sanduka veya kapak taşı olmak üzere on sekiz mezar taşı incelenmiştir.

Çalışmada depoda yer alan mezar taşlarının yüzeylerinde bulunan kitabeler okunmuş, figürler sembolik açıdan değerlendirilip ikonografik olarak açıklanmaya çalışılmıştır. Kitabeli mezar taşları kronolojik bir düzen içerisinde sıralanmış ve kitabelerde yer alan isim, unvan, meslek, lakap, akrabalık bağları vb. gibi ifadeler açıklanmıştır. Yazı çeşitleri belirlenerek hangi teknikte yazıldıklarına dikkat çekilmiştir. Taşlar, form, malzeme ve süsleme özellikleriyle detaylı bir biçimde tanıtılmıştır. Türk-İslam sanatı içerisindeki yeri üzerinde durulmuş olan bu mezar taşlarının müzeye nereden getirildikleri belirtilerek kültürel, sanatsal çeşitlilik açısından dönemi içerisindeki yeri vurgulanmıştır.

Anahtar Kelimeler: Diyarbakır, müze, mezar taşı, sembol, kitabe.

\section{A Group of Tombstones Found in Diyarbakır Archaeological and Ethnographic Museum Depot}

\section{Abstract}

Grave stones that have an important place among our tangible cultural assets are very valuable in terms of history, art, literature and culture. These works,

* Dr. Öğretim Üyesi, Dicle Üniversitesi, Edebiyat Fakültesi, Sanat Tarihi Bölümü, cinarsahure@gmail.com 
which constitute an important group in terms of Turkish-Islamic art, are neither understood early enough nor protected as necessary. For this reason, some of them have disappeared. Some of them are in the museum repository. In this study, eighteen tombstones were investigated in Diyarbakır Archaeological and Ethnographic Museum, including twelve headstones and six stones consisting of one foot stone, two side stones which belong to the tomb and three ledgers.

The inscriptions on the surface of the tomb stones in the depot were read, the figures were evaluated symbolically and tried to be iconographically explained. The tombstones are listed in a chronological order and the names, titles, professions, nicknames, kinship ties etc. on the inscriptions are described. The types of writing were determined and attention was paid to which technique they were written. Stones are introduced in terms of their form, material and decoration. It is stated that why those tombstones, which have been emphasized many times before in terms of their place in Turkish-Islamic Art, have been brought to the museum and their importance in the period they belong to, in terms of diversity in the arts, is underlined.

Keywords: Diyarbakır, museum, tombstone, symbol, inscription.

\section{GİRIŞ}

Mezar taşları yapıldıkları çevrenin ve dönemin inançlarını, sanat geleneklerini, iktisadi ve sosyal şartlarının ortak ürünüdür.

Türklerde mezar geleneği, Türk tarihinin başlangıcından bu güne kadar kesintisiz devam etmektedir. Tarihin en eski dönemlerinden bu yana atalara duyulan büyük saygı nedeniyle mezarlara ayrı bir önem verilmiş ve Türk sanatı tarihinde mezar yapıları ve mezar taşları önemli bir yer almıştır. Türkler kendilerine özgü biçimlere ulaşan, plastik değer taşıyan, genellikle soyut anlayışta mezar taşları meydana getirmişlerdir.

Doğrudan toprağa gömme, hazırlanmış özel bir çukur, oda veya sandık içerisine yerleştirme, toprak üzerine anıt dikme gibi ne şekilde olursa olsun hepsinin temelinde zaman içerisinde farklı yorumlarla şekillenen halk inanışları yatmaktadır. Mezar taşları da bu geleneğin hâlen devam eden bir uygulamasıdır ve ölen kişiye saygı, onun aziz hatırasını ebedî kılma düşüncesinin bir ürünüdür (Ertan, 2012:22; Çerkez, 2000:179).

Çalışmada Diyarbakır Arkeoloji ve Etnoğrafya Müzesi'nin deposunda bulunan on ikisi baştaşı, altısı ayaktaşı olmak üzere on sekiz mezar taşı incelenmiştir. Envanter kayıtlarına göre Diyarbakır’n farklı alanlarından müzeye getirilen bu taşların ölçüleri alınıp, fotoğrafları çekilerek tanıtılmaya çalışılmıştır. 


\section{BAŞTAŞLARI}

Envanter No: 493 / Resim No: 1

Müzeye Getirildiği Yer ve Getiriliş Tarihi: Ali Pınar Köyü/4.12.1953

Kitabesi: $\quad$ Hazâ Merkad-1

Merhûm Alî

Rûhıçün Fâtiha

Sene 1011

(1602-1603)

İşleniş Tarzı: Kabartma / Yazı Türü: Sülüs / Malzemesi: Bazalt taşı

Türü: Erkek / Konumu: Baştaşı

Boyutları: Baştaşı En: 28cm Boy:82,5cm Kalınlık:15cm

\section{Genel Tanım ve Kompozisyon Özellikleri}

Gövdesi dikdörtgen prizma formunda yapılmış olan taşın alınlığı, kaş kemerlidir. Taşın alınlığında sülüs karakterli ve kabartma tekniğinde yazılmış dört satırlık kitabesi vardır. Kitabe, sağa doğru yatık bir şekilde yerleştirilmiştir. Taşın üzerinde süsleme yoktur.

Envanter No: 582 / Resim No: 2

Müzeye Getirildiği Yer ve Getiriliș Tarihi: Ayn Minare Deve Hamamı Sokağı/ 3.9.1954

Kitabesi: $\quad$ Fâtiha ......atâ ....

Halîl Efendinün rûhı

Âbide Hâtun

Sene 1024 ?

(1615-1616)

İşleniş Tarzı: Kabartma / Yazı Türü: Sülüs / Malzemesi: Bazalt taşı

Türü: Kadın / Konumu: Baştaşı

Boyutları: Baştaşı En: $26 \mathrm{~cm}$ Boy:71cm Kalınlık:13cm

\section{Genel Tanım ve Kompozisyon Özellikleri}

Dikdörtgen prizma formda yapılmış olan taş, gövde ve boyun kısımlarından oluşmaktadır. Sülüs karakterli ve kabartma tekniğinde, taşın yüzeyine sağa yatık olarak yazılmış dört satırlık kitabesi vardır. Satırlar düz silmeli kartuşlar içerisine yerleştirilmiştir. Taşın üzerinde süsleme yoktur. 
Envanter No: 492 / Resim No: 3

Müzeye Getirildiği Yer ve Getiriliş Tarihi: Ali Pınar Köyü/ 4.12.1953

Kitabesi: Hazâ Merkad-i Mustâfâ

Hacı Abdullah?

Sene 1150

(1737-1738)

İşleniş Tarzı: Kabartma / Yazı Türü: Sülüs / Malzemesi: Bazalt taşı

Türü: Erkek / Konumu: Baştaşı

Boyutları: Baştaşı En: $34 \mathrm{~cm}$ Boy: $88 \mathrm{~cm}$ Kalınlık:13cm

\section{Genel Tanım ve Kompozisyon Özellikleri}

Dikdörtgen prizma şekilli gövde, kitabenin ilk satırından sonra içe doğru girinti yapıp yukarıya doğru uzanmakta ve sivri kemerli bir alınlıkla sonlanmaktadır. Taşın yüzeyi düz silmeli bir kartuş ile iki panoya ayrılmıştır. Panolarda kabartma tekniğinde ve sülüs karakterli kitabe metnine yer verilmiştir. İlk panoda bir satır, ikinci panoda ise iki satır kitabe metni yer almaktadır. Taş süslemesizdir.

\section{Envanter No: 1 / Resim No: 4}

Müzeye Getirildiği Yer ve Getiriliş Tarihi: Getirildiği yer ve tarih kayıt edilmemiştir.

Kitabesi: Hazâ

Ümmî hatun ?.....

Sene 1155

(1742-1743)

İşleniş Tarzı: Kabartma / Yazı Türü: Sülüs / Malzemesi: Bazalt taşı

Türü: Kadın / Konumu: Baştaşı

Boyutları: Baştaşı En: $28 \mathrm{~cm}$ Boy:81cm Kalınlık:14cm

\section{Genel Tanım ve Kompozisyon Özellikleri}

Dikdörtgen prizma gövdeli taş sivri kemerli bir alınlıkla taçlandırılmıştır. Taşın yüzeyinde düz silmeli kartuşlarla ayrılmış üç satırlık kitabe metni yer alır. Kitabe, sülüs karakterli ve kabartma tekniğinde yazılmıştır. Alt kısmı kırık olan taş, süslemesizdir. 
Envanter No: 425 / Resim No: 5

Müzeye Getirildiği Yer ve Getiriliş Tarihi: Kale Camisi/ 2.10.1948

Kitabesi: Hazâ merhûm

......allâh merhûm

Hakkıçün Fâtiha

$1160 ?$

$(1747-1748)$

İşleniş Tarzı: Kabartma / Yazı Türü: Sülüs / Malzemesi: Bazalt taşı

Türü: Erkek / Konumu: Baştaşı

Boyutları: Baştaşı En: $32 \mathrm{~cm}$ Boy:92cm Kalınlık:12cm

\section{Genel Tanım ve Kompozisyon Özellikleri}

Üst kısmı kırık olan taş, dikdörtgen prizma gövdelidir. Düz silmeli kartuşlarla üç kısma ayrılan taşın yüzeyinde sülüs karakterli ve kabartma tekniğinde yazılmış dört satır kitabe bulunmaktadır. Kitabe metninin ilk iki satırı bir kartuş içinde, diğer iki satır ise ayrı ayrı kartuşlar içinde yazılmıştır.

Envanter No: 591 / Resim No: 6

Müzeye Getirildiği Yer ve Getiriliș Tarihi: Urfa Kapı dıșından/ 4.9.1956

Kitabesi: $\quad$ Fâtiha

Hazâ merkad-ı merhûm Hâcı .....dîn

Zâde el-hâcı Ebû Bekir Aga ruhıçün

Sene 1170

(1756-1757)

İşleniş Tarzı: Kabartma / Yazı Türü: Sülüs / Malzemesi: Bazalt taşı

Türü: Erkek / Konumu: Baştaş1

Boyutları: Baştaşı En: $31 \mathrm{~cm}$ Boy:88cm Kalınlık:14cm

\section{Genel Tanım ve Kompozisyon Özellikleri}

Dikdörtgen prizma gövdeli olan taş, sivri kemerli bir alınlıkla tamamlanmıştır. Taşın yüzeyinde kartuşlarla birbirinden ayrılmış dört satırlık kitabe metni yer almaktadır. Sülüs karakterli ve kabartma tekniğinde yazılmış olan kitabenin ilk satırı üç dilimli bir kartuş içinde, son satırı oval kartuş içinde yazılmıştır. Ortadaki iki satır ise düz silmeli bir kartuşla birbirinden ayrılmıştır. Taş, süslemesizdir. 
Envanter No: 495 / Resim No: 7

Müzeye Getirildiği Yer ve Getiriliş Tarihi: Ali Pınar Köyü/ 4.12.1953

Kitabesi: $\quad$ Hazâ merkad-i merhûme

Fâtıma Hâtun

......rûhıçün

fâtiha Sene 1185

$(1771-1772)$

İşleniş Tarzı: Kabartma / Yazı Türü: Sülüs / Malzemesi: Bazalt taşı

Türü: Kadın / Konumu: Baştaşı

Boyutları: Baştaşı En: 28,5cm Boy:97cm Kalınlık:13,5cm

\section{Genel Tanım ve Kompozisyon Özellikleri}

Dikdörtgen prizma gövdeli taş, sivri kemerli bir alınlıkla tamamlanmıştır. Sivri kemerli alınlık, stilize yaprak motifleriyle süslenmiştir. Alınlık ile kitabe birbirinden bir düz silmeli kartuşla ayrılmıştır. Taşın yüzeyinde sülüs karakterli ve kabartma tekniğinde yazılmış dört satırlık kitabesi yer almaktadır. Satırların arasında yine düz silmeli kartuşlar yapılmıştır. Son satırı çevreleyen kartuş, alt kısma doğru uzatılarak sonlandırılmıştır.

Envanter No: 7/1/91 / Resim No: 8

Müzeye Getirildiği Yer ve Getiriliş Tarihi: Kanal kazımı sırasında/ 2.12.1991

Kitabesi: $\quad$ Hazâ

merkad-i merhûm hân agası

Abdulgafûr aga rûhına

Fâtiha Sene 1193

$(1779-1780)$

İşleniş Tarzı: Kabartma / Yazı Türü: Sülüs / Malzemesi: Bazalt taşı

Türü: Erkek / Konumu: Baştaş1

Boyutları: Baştaşı En:34 cm Boy:73cm Kalınlık:12,5cm

\section{Genel Tanım ve Kompozisyon Özellikleri}

Üst kısmı kırık olan taş, dikdörtgen prizma formlu olarak tamamlanmıştır. Sülüs karakterli ve kabartma tekniğinde yazılmış dört satırlık kitabesi vardır. Kitabe satırları düz silmeli kartuşlarla birbirinden ayılmakta olan taş, süslemesizdir. 
Envanter No: 497 / Resim No: 9

Müzeye Getirildiği Yer ve Getiriliş Tarihi: Ali Pınar Köyü/ 4.12.1953

Kitabesi: Fâtiha

Hazâ Merkad-i Merhûm

Ve magfûr

Hüseyin Aga Emîn

Zâde Sene 1241

(1825-1826)

İşleniş Tarzı: Kabartma / Yazı Türü: Sülüs / Malzemesi: Bazalt taşı

Türü: Erkek / Konumu: Baştaş1

Boyutları: Baştaşı En: 29cm Boy:109cm Kalınlık:14cm

\section{Genel Tanım ve Kompozisyon Özellikleri}

Sivri kemer şeklinde tamamlanmış olan taş, dikdörtgen prizma formdadır. Sülüs karakterli ve kabartma tekniğinde yazılmış olan beş satırlık kitabesi vardır. Satırlar sağa yatık bir şekilde, düz silmeli kartuşlar içerisine yerleştirilmiştir. Taşın üzerinde süsleme yoktur.

Envanter No: 428 / Resim No: 10

Müzeye Getirildiği Yer ve Getiriliş Tarihi: Melik Ahmet Parlu Kapıs1/ 2.10.1948

Kitabesi: Hüve’l-bâkî

Hazâ merkad-i merhûm ve magfûr

Otrakçı Ali Efendinün

Cemîle Hâtûn

Rûhına el-Fâtiha

Sene 1326

(1908-1909)

İşleniş Tarzı: Kabartma / Yazı Türü: Sülüs / Malzemesi: Bazalt taşı

Türü: Kadın / Konumu: Baştaşı

Boyutları: Baştaşı En: $29 \mathrm{~cm}$ Boy:128cm Kalınlık:13cm

\section{Genel Tanım ve Kompozisyon Özellikleri}

Dikdörtgen prizma gövdeli taş, sivri kemer şeklinde bir alınlıkla tamamlanmıştır. Süslemesiz olan taşın sülüs karakterde ve kabartma tekniğinde yazılmış altı satırlık kitabesi 
vardır. Kitabe satırları düz silmeli kartuşlarla birbirinden ayrılmıştır.

Envanter No: 494 / Resim No: 11

Müzeye Getirildiği Yer ve Getiriliş Tarihi: Ali Pınar Köyü/ 4.12.1953

Kitabesi: Yâ Hayy

Bu kabirde ukde-i hâk-i

Gufrân olan kâtib

Hâcı Ahmed Efendinün

Mahdûmı ve on tokuzunc1

Yigirminci alayun emîni

Abdulkâdir Efendinün rûhına

Fâtiha Sene 1327

(1909-1910)

İşleniş Tarzı: Kabartma / Yazı Türü: Sülüs / Malzemesi: Bazalt taşı

Türü: Erkek / Konumu: Baştaş1

Boyutları: Baştaşı En: $28 \mathrm{~cm}$ Boy:91cm Kalınlık:13,5cm

\section{Genel Tanım ve Kompozisyon Özellikleri}

Dikdörtgen prizma formda olan taşın üst kısmı kırılmıştır. Taş, satırları sağa yatık bir şekilde, düz silmeli kartuşlarla ayrılan sekiz satırlık kitabeye sahiptir. Kitabe, sülüs karakterli ve kabartma tekniğinde yazılmıştır. Kitabenin ilk satırının sonunda yukarıdan aşağıya doğru sarkan iki süsleme unsuru yer alır. Taşın üst kısmı kırık olduğu için bu süslemelerin ne olduğu tespit edilememiştir.

Envanter No: 426 / Resim No: 12

Müzeye Getirildiği Yer ve Getiriliş Tarihi: Kale Camisi/ 2.10.1948

Kitabesi: $\quad$ Hazâ

Merkad-1 Merhûm magfûr

Veznedâr agazâde

Şamir?? Efendinün

Rûhına el-Fâtiha 
Sene 1338

(1919-1920)

İşleniş Tarzı: Kabartma / Yazı Türü: Sülüs / Malzemesi: Bazalt taşı

Türü: Erkek / Konumu: Baştaş1

Boyutları: Baştaşı En: 27,5cm Boy:118cm Kalınlık:13cm

Genel Tanım ve Kompozisyon Özellikleri

Alınlığı sivri kemerle tamamlanmış olan taş, dikdörtgen prizma gövdelidir. Düz silmeli kartuşlarla birbirinden ayrılmış yedi satırlık kitabesi vardır. Kitabe, sülüs karakterli ve kabartma tekniğinde yazılmıştır.

\section{AYAKTAŞI, KAPAK TAŞI, SANDUKA VEYA ÇATMA LAHİTE AİT YAN TAŞI}

Envanter No: 15/2/84 / Resim No: 13 / Çizim No: 1

Müzeye Getirildiği Yer ve Getiriliş Tarihi: Abdullah Güner'den satın alma/ 27.7.1984

İşleniş Tarzı: Kabartma / Malzemesi: Bazalt taşı / Konumu: Ayaktaşı

Boyutları: Ayaktaşı En: $29 \mathrm{~cm}$ Boy:118cm Kalınlık:12,5cm

\section{Genel Tanım ve Kompozisyon Özellikleri}

Dikdörtgen prizma formundaki taş üzerinde süsleme unsurlarına yer verilmiştir. Taşın taç kısmından aşağıya doğru uzanan, uç kısmı yuvarlaklaştırılmış bir hançer vardır. Taşın orta kısmında yün eğrilten iğ denen bir alet, en alt kısımda bele bağlanan kama veya fişek konulan bir kemer yapılmıştır.

Envanter No: 463 / Resim No: 14 / Çizim No: 2

Müzeye Getirildiği Yer ve Getiriliş Tarihi: Mardin Kapı Belediye Park1/ 25.5.1950

İşleniş Tarzı: Kabartma / Malzemesi: Bazalt taşı / Konumu: Sanduka veya kapak taşı

Boyutları: Ayaktaşı En: 17,5cm Boy:69cm Kalınlık:23cm

Genel Tanım ve Kompozisyon Özellikleri

Dikdörtgen prizma formda bir taştır. Taşın yüzeyine dikey olarak yapılmış üst kısımda hançer, alt kısımda ise makas yer alır.

Envanter No: 593 / Resim No: 15 / Çizim No: 3

Müzeye Getirildiği Yer ve Getiriliş Tarihi: Urfa Kapı dışından/ 4.9.1956 
İşleniş Tarzı: Kabartma / Malzemesi: Bazalt taşı / Konumu: Çatma TipiLahit’e ait yan taşı Boyutları: Ayaktaşı En: $28 \mathrm{~cm}$ Boy: $78 \mathrm{~cm}$ Kalınlık:20cm

\section{Genel Tanım ve Kompozisyon Özellikleri}

Taş, dikdörtgen prizma formdadır. Taşın orta bölümüne yapılmış olan niş, alt ve üst kısımlardan dilimli bir şekilde tamamlanmıştır. Niş içerisinde bir servi motifi işlenmiştir. Servinin kenarlarında nar meyveleriyle çerçeve yapılmıştır. Bu çerçeve tekrar edilmiş ve içerisinde bir başak motifi yer almaktadır. Bu motiflerin kenarlarında yuvarlak şekilde yapılmış nar meyvesi işlenmiştir.

Envanter No: 453 / Resim No: 16 / Çizim No: 4

Müzeye Getirildiği Yer ve Getiriliş Tarihi: Zirai Donatım Binası/ 29.11.1949

İşleniş Tarzı: Kabartma / Malzemesi: Bazalt taşı / Konumu: Çatma Tipi Lahit’e ait yan taşı

Boyutları: Ayaktaşı En: $26 \mathrm{~cm}$ Boy:88cm Kalınlık:23,5cm

\section{Genel Tanım ve Kompozisyon Özellikleri}

Dikdörtgen prizma formda yapılmıştır. Orta kısımda üstten ve alttan uçları sivri bir kartuş içerisinde süsleme unsurlarına yer verilmiştir. Kartuşun ortasında aşağıya doğru uzanan bir kılıç ve kılıcın bir yanında tesbih diğer yanında ise bıçak yapılmıştır.

\section{Envanter No: 594 / Resim No: 17 / Çizim No: 5}

Müzeye Getirildiği Yer ve Getiriliş Tarihi: Urfa Kapı dışından/ 4.9.1956

İşleniş Tarzı: Kabartma / Malzemesi: Bazalt taşı / Konumu: Sanduka veya kapak taşı

Boyutları: Ayaktaşı En: $31 \mathrm{~cm}$ Boy:62cm Kalınlık:17,5cm

\section{Genel Tanım ve Kompozisyon Özellikleri}

Dikdörtgen prizma formdaki taşın orta kısmında dikdörtgen, alt kısmında ise altıgen şeklinde içe doğru derinlik yapılmıştır. Bu derinlikleri mihraplı seccade formunda süsleme öğesi çevrelemektedir. Mihrabın üst kısmında birbirine bakar vaziyette birer lale motifi bulunmaktadır. Mihrabın sağ tarafında ibrik, sol tarafında ise bir kandil motifi yer alır. Motifleri çerçeve içerisine alan seccadenin bordür bölümünde zeminde şamdanlar yapılmıştır.

Envanter No: 592 / Resim No: 18 / Çizim No: 6

Müzeye Getirildiği Yer ve Getiriliş Tarihi: Urfa Kapı dışından/ 4.9.1956

İşleniş Tarzı: Kabartma / Malzemesi: Bazalt taşı / Konumu: Sanduka veya kapak taşı 


\section{Boyutları: Ayaktaşı En: $30 \mathrm{~cm}$ Boy: $66 \mathrm{~cm}$ Kalınlık:25cm}

\section{Genel Tanım ve Kompozisyon Özellikleri}

Dikdörtgen prizma formundaki taşın sağ köşesi kırılmıştır. Taş, mihraplı seccade şeklinde süslenmiştir. Üst kısmı sivri kemerli olarak tasarlanmış olan mihraplı seccadenin orta kısmında saçları örgülü, yüz ifadesi olmayan bir kadın motifi işlenmiştir. Bu motifin alt kısmında yatay olarak yapılmış geometrik motiflerle seccade ikiye ayrılmıştır. İkinci bölümü oluşturan alt kısımda çerçeveler içerisine alınmış birer gülabdan motifleri yer almaktadir.

\section{DEĞERLENDİRME}

Bu çalışmada Diyarbakır Arkeoloji ve Etnoğrafya Müzesi deposunda bulunan on sekiz mezar taşı ele alınmıştır. Bu taşların on ikisi kitabeli baştaşıdır². Son altı taş ile ilgili değerlendirme kısmında kesin bir şey söylemek mümkün olmamakla birlikte bunların ayaktaşı, sanduka veya lahit tipi mezarlara ait yan taşı olabileceğini ihtimal olarak vurgulamakta yarar var. Figüratif süslemeye sahip 1 adet ayaktaşı ${ }^{3}, 3$ adet sanduka veya kapak taş. $1^{4}$ ve 2 adet çatma lahite ait yan taş $1^{5}$ vardır. Müzede bulunan bu taşlar detaylı bir şekilde incelenerek tanıtılmış, kitabeli olanların kitabeleri okunmuştur. İncelenen taşların hepsi yekpare taşlardan yapılmış olup genellikle aynı formlarda değerlendirilmiş örneklerdir.

Değerlendirilen kitabeli on iki mezar taşının sekizi erkek ${ }^{6}$, dördü ise kadın ${ }^{7}$ mezar taşıdır. İncelenen figürlü altı mezar taşının ${ }^{8}$ ise kimlikleri konusunda kesin bir bilgi bulunmamakla birlikte, 592 envanter nolu taşın üzerindeki yüz ifadesi olmayan saç örgülü kadın motifine ve 15/2/82 envanter nolu taşın üzerinde ise yün eğirmek için kullanılan "iğ" adı verilen aletin yapılmış olmasına bakarak bu taşların kadın mezar taşı olması muhtemeldir.

Depodaki bu taşların en erken tarihlisi 1602-1603 tarihli olan 493 envanter nolu, en geç tarihlisi ise 1919-1920 tarihli 426 envanter nolu taştır.

Müzede yer alan ayaktaşlarının altısında süsleme bulunmaktadır. Süsleme programlarına bakıldığında bitkisel motif iki örnekte ${ }^{9}$ görülmektedir. 593 envanter nolu örnekte niş içerisinde en dışta "Allah" lafzının ilk harfi olan "Elif” e benzetilen ve sallanırken yapraklarından çıkan "hû" sesi ile Allah'ı zikrettiğine inanılan (Ersoy, 2002:93; Doğanay, 2004:136), aynı zamanda kabir ağacı olarak da bilinen (Ertan, 2012:155; Tali, 2013:386) bir

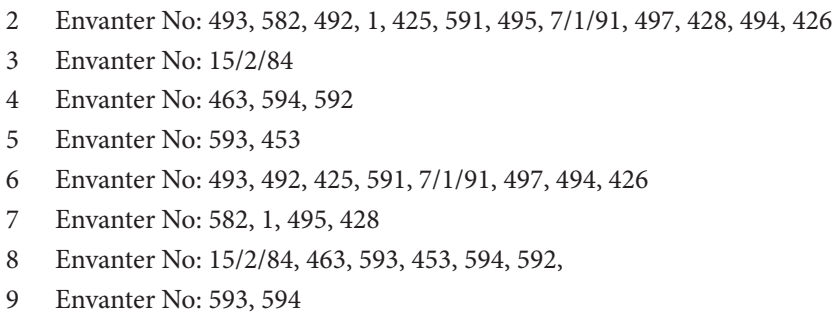


servi ve içerisinde Ön Asya ve Doğu Akdeniz bölgelerine ait yazılı kaynaklarda ölüm ve doğum döngüsünün temsili bir değeri olarak dikkat çekilen (Tiryaki, 2013:45), yaşamın sona ereceğini sonsuz bir hayatın başlangıcı olduğunun temsili olan bir başak motifi yer almaktadır. Bu motiflerin kenarlarında yuvarlak şekilde yapılmış bereket motifi olarak sonsuz mutluluk dileğini ifade eden nar (Er ve Hünerel, 2013:173) meyvesi bulunmaktadır. Diğer bitkisel motifli mezar taşı ise 594 envanter nolu taştır. Üzerinde yapılmış mihraplı seccade formunda süsleme öğesinin üst kısmında birbirine bakar vaziyette, "Vahdet-i Vücud" yani Allah'ı sembolize eden (Süheyl, 1971:268), güzellik ve zarafetin sembolü olan (Daş ve Çakmak, 2013:35) birer lale motifi bulunmaktadır. Mihrabın sağ tarafında mezarda yatan kişinin hayatta iken abdestli, namazlı, kâmil bir Müslüman veya cömert, hayırsever bir insan olduğunu anlatan (Örnek, 1979:71) ibrik, sol tarafında ise aydınlığın sembolü (Özkan, 2000:35) olduğundan mezar taşlarında ölünün yolunu ve kabrini aydınlatıcı bir mana taşıyan (Bakırcı, 2005:108) bir kandil motifi yer alır. Motifleri çerçeve içerisine alan seccadenin bordür bölümünde zeminde şamdanlar yapılmıştır. Işı̆̆̆ nuru ifade eden şamdan (Biçici, 2012:640), kandil gibi mezarda yatanın yolunu aydınlatması anlamında işlenmiştir.

Depoda yer alan bezemeli diğer dört mezar taşında sembolik olarak farklı anlamları olan motifler işlenmiştir. 15/2/48 ve 463 envanter nolu mezar taşlarında hançer motifine yer verilmiştir. Sadece erkekler arasında değil, kadınlar arasında da kullanılan bir motif olan hançer, kadınların bellerine taktıkları gümüş kemerde, işlemeli küçük bir süsleme unsuru olarak da kullanılmıştır. Mezar taşlarına kılıç, hançer motifi işleme geleneği, Selçuklulardan sonra, Osmanlı medeniyetinde de karşımıza çıkmaktadır. Özellikte İstanbul' da, Klasik Osmanlı Dönemi üstü açık lahit veya sandukalar üzerinde de kullanıldığı görülmektedir. İstanbul'daki hançerli lahitlerin kitabeli olanlarının tamamının hanedan üyesi veya yüksek tabaka mensubu olmaları bu motifin bir asalet sembolü olarak kullanılmış olabileceğini düşündürmektedir. İstanbul'daki sandukalarda ölen kişinin ölüm nedeninin verilmemesine rağmen hanedan üyesi olmaları, bu figürlerin önemli kişileri sembolize etmek amacıyla Türk sanatı ve kültüründe kullanılmış olabileceğini göstermektedir (Çoruhlu, 1997:43-44).

15/2/84 envanter nolu taşın yüzeyinde yün eğirmek için kullanılan “iğ" denen alet ve bele bağlanan hançer konulan kemer yapılmıştır. Yün eğirilen aletin işlenmesinden dolayı bu taşın bir kadın mezar taşı olabileceğini söylemek mümkündür.

463 envanter nolu taşta ise hançerin yanı sıra makas motifi işlenmiştir. Türklerde, beldeki kemere bıçak, kılıç, hançer veya silah asma geleneği çok eskidir (Baştay, 2005:268-271). Çin kaynaklarında, Kırgızlar'da hemen herkesin kemerinde takılı bıçak-hançer vardır. Hazarlar'a ait mezarlarda da ölen her erkeğin yanında, kınlı veya kınsız bir bıçağın konulması, gelenektir (Ögel, 1962:209).

453 envanter nolu taş üzerinde kılıç, bıçak ve tesbih beraber işlenmiştir. Tespihin menşei bilinmemektedir. Fakat on birinci yüzyılda manastırlarda dua edilirken kullanılmıştır. Bazı tarikat mensupları kemerlerinde tesbih taşıma mecburiyetleri vardı (Ülkümen, 1970:111). Namazlarda tesbih çekmek adettir. Namaz sonlarında otuz üçer defa "Sübhanâllah, 
Elhamdülillâh ve Allahuekber" denilmesi sebebiyle tesbih İslam âleminde genellikle doksan dokuzdur. Türk el sanatları içerisinde önemli bir yere sahip olan tesbih motifi, yaygın olmamakla birlikte mezar taşlarında da kullanılmıştır. Dünyada yaşanılan ömrün tesbih gibi çekilip bitti gibi manevi anlamlar taşımaktadır.

592 envanter nolu taş, mihraplı seccade şeklinde süslenmiştir. Üst kısmı sivri kemerli olarak tasarlanmış olan mihraplı seccadenin orta kısmında saçları örgülü, yüz ifadesi olmayan bir kadın motifi işlenmiştir. Bu motiften dolayı taşın bir kadına ait olduğunu söylemek mümkündür. Bu motifin alt kısmında yatay olarak yapılmış geometrik motiflerle seccade ikiye ayrılmıştır. İkinci bölümü oluşturan alt kısımda çerçeveler içerisine alınmış birer gülabdan motifleri yer almaktadır.

$\mathrm{Bu}$ araştırmada ele alınan on sekiz mezar taşından on ikisi kitabelidir. Taşlar üzerindeki kitabeleri oluşturan yazı kuşakları "sülüs" hatla kabartma tekniğinde yazılmıştır. Bu kitabeler basit kartuşlarla ayrılarak taşın yüzeyine beşi yatay ${ }^{10}$, altısı ${ }^{11}$ ise düz olarak yerleștirilmiştir. Mezar taşlarındaki ilk satırlarda, "Hüvel Bâki' ${ }^{12}$ (O ebedidir), Ya Hayy ${ }^{13}$, Hazâ merhum (Allah’nn rahmetine kavuşan bu), Merhum ve mağfur gibi yakarışlar kullanılmıştır. Ayrıca mezarın kime ait olduğunu belirten ifade olarak da "Hazâ Merkad-1 (Bu mezar) ifadesi incelenen taşlardan dokuz kitabede tekrarlanmıştır ${ }^{14}$. Bazı örneklerde ise doğrudan mezarda yatan kişinin kimlik bilgileri ile başlanıp kitabeler dua ve tarih ibaresi ile tamamlanmıştır ${ }^{15}$. Kimlik bilgilerinde bazen yatanın kendi adı ile birlikte baba adı, kocasının adı ve sülale adları ile birlikte verilmiştir. Hacı zade, Veznedar Ağazade, Hüseyin Ağa Eminzade tespit edilen sülale isimleridir ${ }^{16}$. Erkek mezarlarında " $\mathrm{Hac1}$, Efendi, Ağa" gibi unvanlar ${ }^{17}$ kullanılırken kadın mezarlarında ise "Hatun" ibaresi kullanılmıştır ${ }^{18}$. Kullanılan bu unvanlar arasında kronolojik bir sıralama bulunmamakla birlikte sosyal konumları arasındaki derece farkı olması ihtimalini güçlendirmektedir.

İncelenen mezar taşlarında kalıp şeklinde yazılan dualar uygulanmıştır. Bunun yanı sıra meslek gibi belirleyici unsurlar yalnızca 428 Envanter nolu mezar taşında "Ortakçı"19 (Barkan, 1980:575) ifadesi yazılmıştır. Kitabelerin amac1, mezarda yatan kişinin kimlik bilgilerini vermektir. Kısa yazılmış bu kitabelerde mezarda yatan kişinin ölüm sebebi, hastalık gibi detaylara yer verilmemiştir. Ölünün ruhuna istenen dualar dişında (Ruhiçün

10 Envanter No: 493, 582, 497, 428, 494

11 Envanter No: 492, 1, 425, 591, 495, 7/1/91, 426

12 Envanter No: 428

13 Envanter No: 494

14 Envanter No: 493, 492, 591, 495, 7/1/91, 497, 425, 428, 426

15 Envanter No:493, 492, 1, 425, 591, 495, 7/1/91, 497, 428, 426

16 Envanter No: 591, 426, 497

17 Envanter No: 582, 494, 426, 492, 591, 7/1/91, 497

18 Envanter No: 582, 1, 495, 428

19 Ortakçı: Ortakçı kullar devlete ait hassa çiftliklerinde çalışırlar. Ziraat alanlarında istihdam edilen ortakçı kulların hukukî statüsü Batı’daki kölelik anlayışından farklıydı. Gerçek kölelikle hür kölelik arasında bir sınıf olan ortakçı kullar, XVI. yüzyılda reâyâ sınıfına dahil edilmiştir. 
fatiha, Fatihai Ruhuna el fatiha) serzeniş ifadeleri olan Âh Minel Mevt, Âh Ölüm, El Fırâk gibi (Tali, 2013:387) tamlamalar kullanılmamıştır.

Envanter kayıtlarına göre büyük bir kısmı Diyarbakır’n farklı alanlarından toplanarak müze koleksiyonuna kazandırılmış olan bu mezar taşlarının kitabelerinde üslup birliği bulunmamaktadır. Hem çokbasit ${ }^{20}$ hem de çokitina ${ }^{21}$ ile yazılmışörnekler yer alır. Osmanlıca yazılan bu kitabelerde iş̧̧iliğin farklılaşması mezarda yatan kişinin ekonomik gücü ile alakalı olması muhtemeldir. Taşların hiçbirinde herhangi bir sanatçı imzasının olmayışı da bu kitabelerin yerel ustalar tarafından yapılmış olma ihtimalini güçlendirmektedir. Çalışmadaki mezar taşlarında tarihler, genellikle sadece yıl olarak verilmiştir.

Sosyal hayatın yansıması olarak yapılan, bazen yekpare, bazen de yere yerleştirilerek dikilen Osmanlı dönemi kavuk ve başlıkları (Uluçam, 2000:9), şahide üzerinde bulunan kitabeyi okumadan, ölünün cinsiyetinin belirlenebilme kolaylığını sağlayan bir sembol olmuştur (Koçu, 1967:115). Toplumların veya bir sınıfın alameti olarak kullanılmış, dini ve milli bir gelenek haline gelmiş (Önder, 1958:13; Sürün, 2006:303-397) olan bu başlıklar, 582 envanter nolu taşta önceden var olduğu boyun kısmının varlığından anlaşılabilir. İncelenen diğer on yedi mezar taşının ise tac kısımlarının ya sivri kemer ya da kaş kemer şeklinde sonlandığı için başlık yapılmamıştır.

Koruma ve onarım bakımından gerektiği ilgiyi görmeyen mezar taşları, özellikle İstanbul, Anadolu ve Balkanlar'da yapılan çalışmalarla son yıllarda değeri vurgulanmaya başlanılmıştır. Bu araştırmalarla İstanbul, Anadolu ve Balkanlar'daki pek çok mezar taşı tanıtılmıştır. Bununla birlikte özellikle ülkemizin değişik müze ve hazirelerinde hala ele alınmayı bekleyen pek çok mezar taşı bulunmaktadır. Bu müzelerden biri de Anadolu'nun tarihi kentlerinden biri olan Diyarbakır'da yer alan Arkeoloji ve Etnoğrafya Müzesi'dir.

Diyarbakır Arkeoloji ve Etnoğrafya Müze deposunda ele aldığımız prizmal dikdörtgen gövdeye sahip mezar taşları, form ve süsleme özellikleriyle Osmanlı dönemine ait başka merkezlerdeki örneklerle benzerlik göstermektedir.

Diyarbakır Arkeoloji ve Etnoğrafya Müzesi’nde deposunda değerlendirilmeye çalışılan bir grup mezar taşlarından özellikle kitabeli olanlar Diyarbakır ve civarındaki mezar taşları ile karşılaştırıldığında merkezdeki Mardin Kapı Mezarlığı’nda (İlhan, 1996:182), Diyarbakır Rağibiye Medresesi Mezarlığı’nda ve İskender Paşa Cami Haziresi’nde rastlamaktayı.

İncelenen taşlardan sivri kemer formunda tamamlanmış olan baştaşlarının ${ }^{22}$ benzer örneklerini Erken Osmanlı döneminde özellikle Bursa’da yaygın bir şekilde kullanıldığı ve daha sonra İstanbul ve Anadolu'da tercih edilen bir form olmuştur (Karaçağ, 1994:10-

20 Envanter No: 493, 425

21 Envanter No: 582, 492, 1, 591, 495, 7/1/91, 497, 428, 494, 426

22 Envanter No: 492, 1, 591, 495, 497, 428, 426 
15). Benzerlerinde Tarsus Arkeoloji ve Etnoğrafya Müzesi’nde (Yıldırım, 2013:306), İstanbul Üsküdar'da Rum Mehmet Paşa Cami Haziresi'nde (Yariş, 2015:65), Kayseri Tavlusun Köyü Mezarlığg’nda (Tali, 2012:97-124), Ayaş Sinanlı Köyü Cami Haziresi’nde (Tunçel, 2005:285), Beyşehir Eşrefoğlu Süleyman Bey Külliyesindeki Türbelerde (Muşmal vd., 2014:174), İzmir Karşıyaka Mezarlıklarından Dedebaşı (Kayalar) Mezarlığı'nda (Daş,ve Çakmak, 2013:16), Bitlis Saidiye Türbesi Haziresi'nde (Pektaş, 2001:298) rastlamaktayız ${ }^{23}$. Balkanlarda bu tarz baştaşları Üsküp Yahya Paşa Cami Haziresi’nde (Tunçel, 2010:246) görmek mümkündür.

Depoda yer alan baştaşlarından 493 envanter nolu taş, kaş kemer şeklinde tamamlanmıştır. Benzer örneklerini İzmir Karşıyaka Mezarlıklarından biri olan Dedebaşı (Kayalar) Mezarlı̆̆ı'nda (Daş ve Çakmak, 2013:26), Hakkari Kızıl Kümbet Mezarlığı'nda (Top, 2010: 254) görmek mümkündür.

İncelenen taşlardan sanduka veya kapak taş ${ }^{24}$, çatma tipi lahite ait yan $\operatorname{taş}^{25}$ olarak nitelendirdiğimiz eserlerin benzer en güzel örneklerine Bitlis Ahlat Mezarlı̆̆ı'nda (Karamağaralı, 1992:9-15; Denizli, 2014:24) rastlamaktayı.

Müzede yer alan mezar taşlarından sade mezar taşı yapma geleneğinin devan ettiği örnekleri görmek mümkündür. İncelenen on sekiz mezar taşı kullanılan malzeme genellikle yöreye ait bazalt taşıdır.

Envanter kayıtlarına göre büyük bir kısmı Diyarbakır’ın farklı alanlarından toplanarak müze koleksiyonuna kazandırılmış ve sanat tarihi bakımından da etraflıca ele alınmamış, on sekiz mezar taşı form, malzeme ve süsleme özellikleriyle detaylı bir biçimde tanıtılarak Anadolu-Türk Sanatı içerisindeki yeri vurgulanmaya çalışılmıştır.

\section{SONUÇ}

İnsanlığın var olduğu andan itibaren ölünün öbür dünyaya uğurlanması ve gömülmesi, tüm toplumlarda en önemli dini ritüeller arasında yerini almıştır (Aslanapa, 1972:7-8; Çoruhlu, 1993:38).

Mezar taşları yapıldıkları çevrenin ve dönemin inançlarının, sanat geleneklerinin, sosyal ve iktisadi şartlarının ortak ürünüdür. Bünyesinde bulundurduğu yazı ve süsleme kompozisyonlarıyla sanat tarihi başta olmak üzere birçok bilim dalına kaynaklık eden mezar taşları; döneminin sanat zevkinin, tarihinin ve kültürünün yanı sıra, bulunduğu çevrenin şifrelerini vermekte, askeri, sosyal, kültürel, dinsel, ekonomik ve ticari durumlarını öğrenmede ortaya koyduğu veriler nedeniyle de oldukça önemlidirler. Ayrıca mezar taşları, eski Türk şehirlerinin geçmişine şahitlik eden birer belge

23 Dikdörtgen prizma formunda olup üst kısımda ise sivri kemerli olarak tamamlanan karşılaştırma örneklerinin sayısı çok daha fazla sayıdadır. Bu makale kapsamında belli başı örnekler alınmıştır.

24 Envanter No: 463, 594, 592

25 Envanter No: 593, 453 
niteliğindedirler.

Diyarbakır Arkeoloji ve Etnoğrafya Müzesi deposunda bulunan bir grup mezar taşı ile ilgili yapılan araştırmada genellikle sade örnekler olan 18 mezar taşı incelenmiştir. 12 taş $^{26}$ yüzeyinde kitabeye yer verilmiş, 6 taş ${ }^{27}$ yüzeyinde ise süsleme unsurları kullanılmıştır. Kitabeli taşlar, 1603-1920 yılları arasındaki tarih aralığında yapılmıştır. Okunan kitabelerden yörede yaşayan nüfuzlu ailelerin var olduğu anlaşılmaktadır.

Erkek ve kadın mezar taşları olan bu taşlar yöreye ait bazalt taşından yapılmıştır. Süsleme unsuru olarak ikonografik anlamların yüklendiği motiflerin uygulandığı görülmektedir (başak, hançer, kılıç, bıçak, makas, tesbih). Gerek taşların müzeye getirilişi sırasında gerekse zamanın yaptığı tahribatla taşların bir kısmı kırılmış, bir kısmının üzerindeki kitabeler erimiş̦tir.

Dünden bugüne birçok tarihi bilgiye arşivlik eden mezar taşı kitabeleri, tarihi yönden sundukları bilgiler dışında, edebi ve folklorik özellikleriyle içinde bulundukları toplumun da sosyo-kültürel yapısını yansıtan, milletimizin geçirdiği kültür safhalarını aktaran, birinci elden kaynak durumundadırlar. Bu tarihi belgelerin korunabilmesi için bakımlarının yapılması, halkın bilinçlendirilmesi ve halka gereken eğitim verilerek farkındalık oluşturulmalıdır.

26 Envanter No: 493, 582, 492, 1, 425, 591, 495, 7/1/91, 497, 428, 494, 426 


\section{KAYNAKÇA}

Aslanapa, O. (1972). Türk Sanatı. İstanbul: Milli Eğitim Bakanlığı Yayınları.

Bakırcı, N. (2005). Mevlevi Mezar Taşları. İstanbul: Rumi Yayınları.

Barkan, Ö. L. (1980). Türkiye’de Toprak Meselesi. İstanbul: Gözlem Yayınları.

Baştay, Ş. (2005). Avrupa Hunları’nda Ölü Kurbanları ve Kazanları. Makaleler, 2, 268-271.

Biçici, H.K. (2012). İznik Müzesindeki Kandil ve Şamdan Motifli Mezar Taşları. Turkish Studies, 3(7). 637-661.

Çerkez, M. (2000). Eyüp Sultan Mezar Taşlarında Kandil Motifleri. III. Eyüp Sultan Sempozyuтu, 339-365.

Çoruhlu, T. (1997). Hançerli Lahitler. I Eyüp Sultan Sempozyumu, 43- 60.

Çoruhlu, Y. (1993). Türk Sanatının ABC’si. İstanbul: Simavi Yayınları.

Daş, E. (2012). İzmir'de Taş Çiçekler (Kemeraltı Hazirelerindeki Mezar Taşları). İzmir: İzmir Büyükşshir Belediyesi.

Daş, E.- Çakmak, Ş. (2013). Karşıyaka’nın Taş Çiçekleri. İzmir: Karşıkaya Belediyesi Kültür Yayını.

Denizli, S. (2014). Ahlat Meydan Mezarlı̆̆ı’ndaki Ejder Figürlü Mezar Taşları. Yüksek Lisans Tezi, Yüzüncü Yıl Üniversitesi Sosyal Bilimler Enstitüsü, Van.

Doğanay, A. (2004). Türklerde Ahiret İnancının Mezar Yapı ve Bezemelerine Tesiri. Sanat ve Bilimleri Dergisi, 1(1), 127-140.

Er, B.- Hünerel, Z. S. (2013). Bir İletişim Aracı Olarak El Sanatları. Yaşam Bilimleri Dergisi, $1(1), 169-177$.

Ersoy, A. (2002). Eyüp’teki Mezar Taşlarında Servi Kültü. V.Eyüp Sultan Sempozyumu, Istanbul, 91-95.

http://www.hakkarikulturturizm.gov.tr

İlhan, M. M. (1996). Diyarbakır'ın Türbe, Yatır ve Mezarlıkları. İslam Dünyasında Mezarliklar ve Defin Gelenekleri, I, 179-211.

Karaçağ, D. (1994). Bursa'daki 14-15. Yüzyıl Mezar Taşları. Ankara: Övendire DanışmanlıkTanıtım Hizmetleri S.T.L.Ş.

Karamağaralı, B. (1992). Ahlat Mezar Taşları. Ankara: Kültür Bakanlığı Yayınları.

Koçu, R. E. (1967). Türk Giyim Kuşam ve Süsleme Sözlüğü. Ankara: Sümerbank Kültür Yayınlar1.

Muşmal, H.- Kunt, İ.- Çetinaslan, M. (2014). Beyşehir Eşrefoğlu Süleyman Bey Külliyesindeki Türbelerde Yer Alan Mezar Taşları. Selçuk Üniversitesi Türkiyat Araştırmaları Dergisi, 1 (35), 165-215. 
Ögel, B. (1962). İslamiyet’ten Önce Türk Kültür Tarihi. Ankara: Türk Tarih Kurumu Yayınlar1.

Önder, M. (1958). Konya Mezar Taşlarında Şekil ve Motif Karakterlerin. Anıt, 22-23, 10 25.

Örnek, S. V. (1979). Anadolu Folklorunda Ölüm. Ankara: Dil-Tarih ve Coğrafya Fakültesi Yayınları.

Özkan, H. (2000). Erzincan ve Çevresinde Orta Asya Türk Geleneğini Sürdüren Bezemeli Mezar Taşları. Atatürk Üniversitesi Türkiyat Araştırmaları Enstitü Dergisi, 15, 31-47.

Pektaş, K. (2001). Bitlis Tarihi Mezarlıkları ve Mezar Taşları. Ankara: Kültür Bakanlığı Sanat Eserleri.

Sürün, M. (2006). İstanbul Şeyh Vefa Cami Haziresi (Mezar Taşları Tipolojisi Üzerine Bir Deneme. Yüksek Lisans Tezi, Marmara Üniversitesi Türkiyat Araştırmaları Enstitüsü, İstanbul.

Tali, Ş. (2012). Kayseri Tavlusun Köyü Mezarlığında Bezemeli Mezar Taşları-II. Atatürk Üniversitesi Güzel Sanatlar Fakültesi Dergisi, 21, 97-124.

Tali, S. (2013). Kayseri/Gesi Mezarlığı Mezar Taşları Üzerine Bir Değerlendirme. Atatürk Universitesi Türkiyat Araştırmaları Enstitüsü Dergisi, 49, 359-390.

Tiryaki, S. G. (2013). Yeni Hitit Sanatı Üzerine İkonografik Araştırmalar (1): Üzüm Salkımı ve/veya Başak Filizi Taşıyanlar. Cedrus I (Akdeniz Araştırmaları Dergisi), 1, 33-53.

Top, M. (2010). Hakkari. Hakkari: Hakkari Valiliği.

Tunçel, G. (2005). Ayaş Mezar Taşları. Sanat Tarihi Dergisi, 14(1), İzmir, 277-307.

Tunçel, G. (2010). Üsküp Yahya Paşa Camii Haziresindeki Mezar Taşları. Ankara Üniversitesi Dil ve Tarih-Coğrafya Fakültesi Dergisi, 50, 243-263.

Uluçam, A. (2000). Eski Erciş Çelebibağı Mezarlı̆̆ı Mezar Taşları. Ankara: Türk Tarih Kurumu.

Ülkümen, P. (1970). Tesbihin Tarihçesi, Yapılışı Tekniği ve Saray Koleksiyondaki Tesbihler. Türk Etnografya Dergisi, 12, 111-122.

Ünver, A. S. (1971). Türkiye’de Lale Tarihi. Vakıflar Dergisi, 9, 265-276.

Yariş, S. (2015). Üsküdar'daki Bir Grup Cami ve Hazirelerindeki Mezar Taşları. Doktora Tezi, Atatürk Üniversitesi Sosyal Bilimler Enstitüsü, Erzurum.

Yıldırım, S. (2013). Tarsus Arkeoloji Müzesi’ndeki Osmanlı Dönemi Mezar Taşları. Ankara Üniversitesi Dil ve Tarih-Coğrafya Fakültesi Tarih Araştırmaları Dergisi, 32(53), 303329. 


\section{ÇİZIMLER}

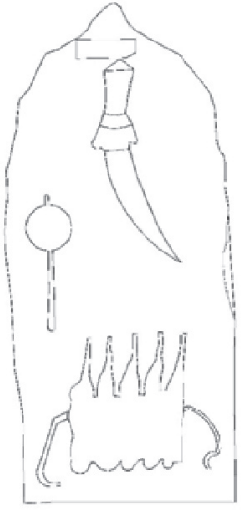

Çizim No 1: Envanter No 15/2/84

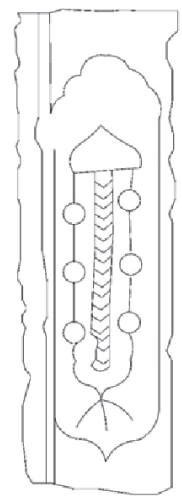

Çizim No 3: Envanter No 593

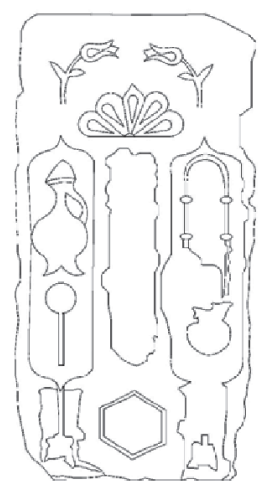

Çizim No 5: Envanter No 594

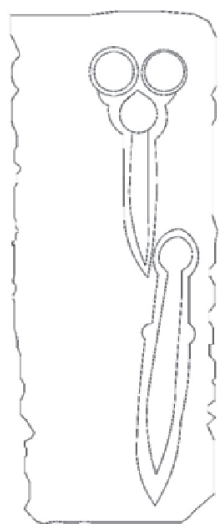

Çizim No 2: Envanter No 463

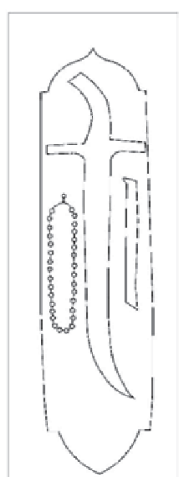

Çizim No 4: Envanter No 453

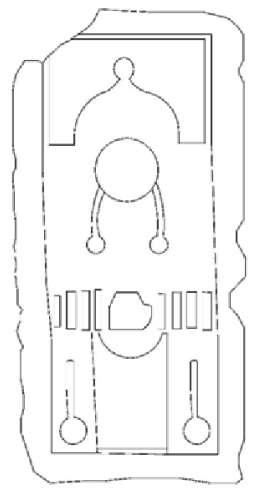

Çizim No 6: Envanter No 592 
RESIMLER

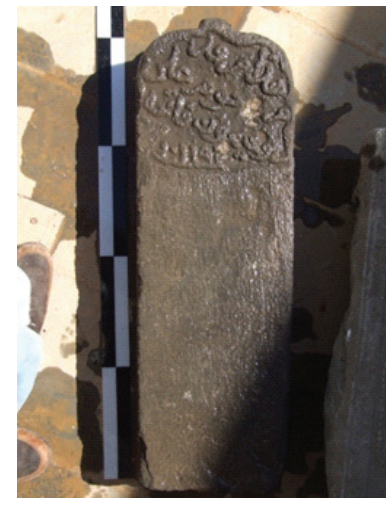

Resim 1: Envanter No 493

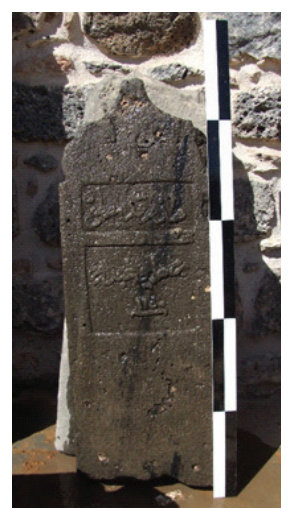

Resim 3: : Envanter No 492

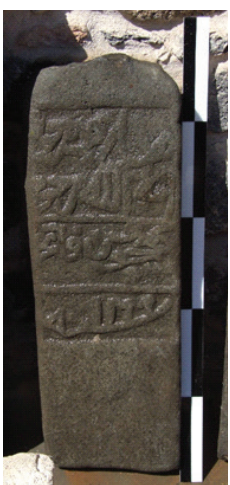

Resim 5: Envanter No 425

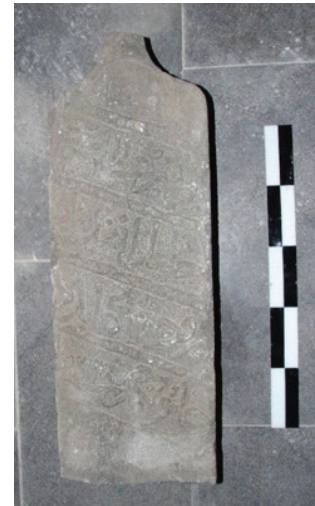

Resim 2: Envanter No 582

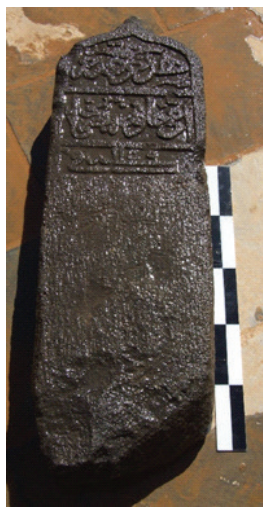

Resim 4: Envanter No 1



Resim 6: Envanter No 591 


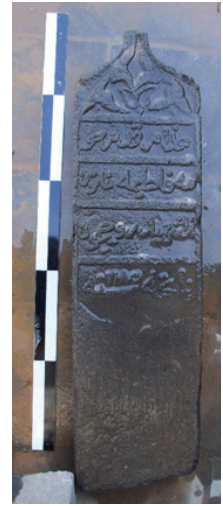

Resim 7: Envanter No 495

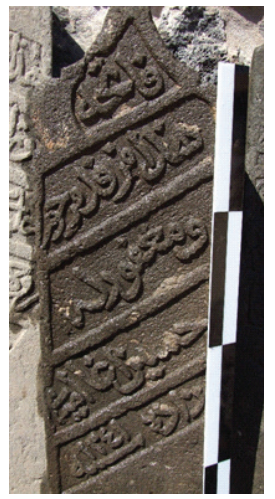

Resim 9: : Envanter No 497



Resim 11: Envanter No 494

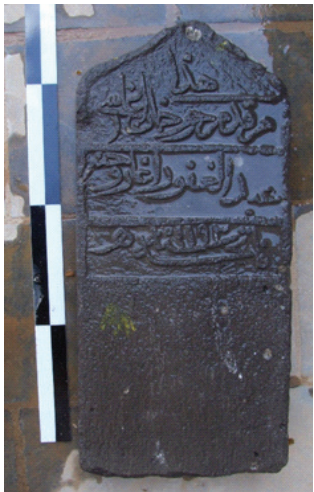

Resim 8: Envanter No 7/1/91

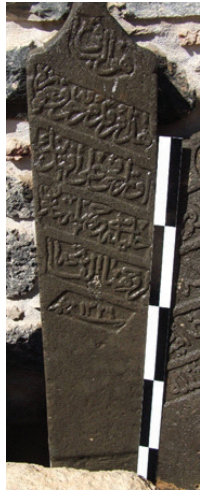

Resim 10: Envanter No 428

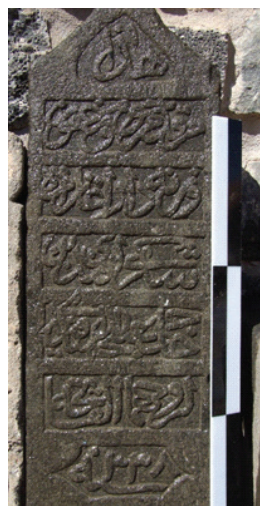

Resim 12: Envanter No 426 


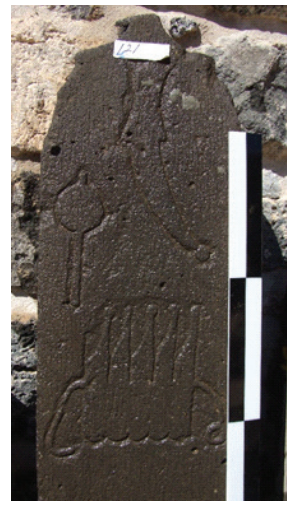

Resim 13: Envanter No 15/2/84

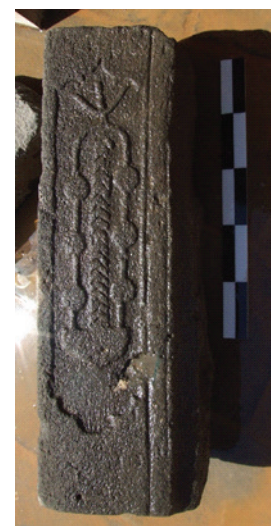

Resim 15: : Envanter No 593

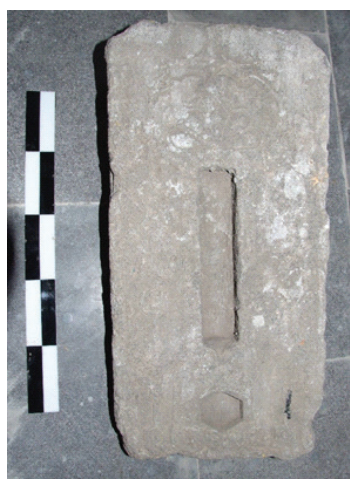

Resim 17: Envanter No 594

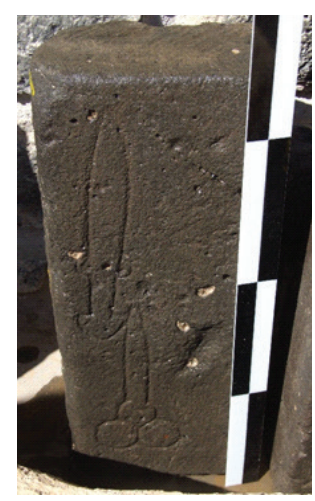

Resim 14: Envanter No 463

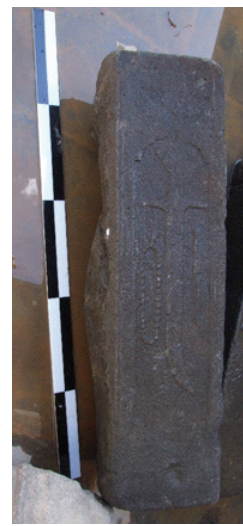

Resim 16: Envanter No 453

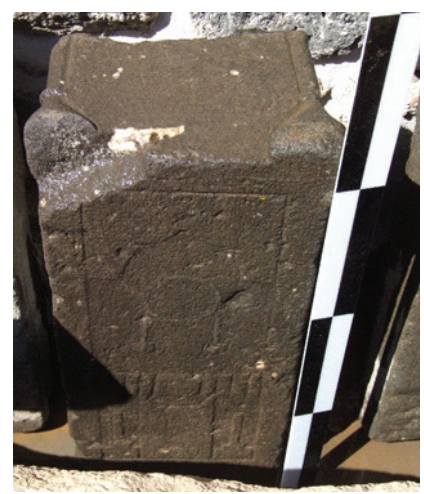

Resim 18: Envanter No 592 